\title{
DYNAMICS OF SOIL MICROBIOLOGICAL ATTRIBUTES IN INTEGRATED CROP-LIVESTOCK SYSTEMS IN THE CERRADO-AMAZONÔNIA ECOTONE ${ }^{1}$
}

\author{
HEIRIANE MARTINS SOUSA ${ }^{2 *}$, AMANDA RIBEIRO CORREA ${ }^{2}$, BÁRBARA DE MOTTA SILVA $^{2}$, SUZANA DA \\ SILVA OLIVEIRA ${ }^{3}$, DANIELA TIAGO DA SILVA CAMPOS ${ }^{4}$, FLÁVIO JESUS WRUCK $^{5}$
}

\begin{abstract}
The combination of grain and livestock production in integrated Crop-Livestock systems (iCLs) provide the opportunity to increase yields, improve soil attributes and ensure the sustainability of the agricultural system. The objective of this research was to evaluate the impact of seven land use systems on their microbiota. Five iCL systems were implemented in 2005 in Santa Carmem, MT, Brazil, with different rotating crops: iCL A (soybean/maize, preceded by two years with pasture), iCL B (rice/maize, preceded by two years with soybean/intercropped pasture), iCL C (soybean/maize, preceded by three years with pasture), iCL D (pasture/maize, preceded by five soybean/maize or millet intercropped with pasture) and iCL E (pasture/maize, preceded by three years with pasture). These were compared with two reference systems: a conventional soybean/maize succession system (CC) and native forest (NF). Soils were collected $(0.00-0.20 \mathrm{~m})$ and the population dynamics of fungi, bacteria, actinobacteria and cellulolytic microorganisms were evaluated over the course of two years (2012 and 2013). Likewise, carbon stocks of microbial biomass (CBM); metabolic quotient $\left(q \mathrm{CO}_{2}\right)$; basal respiration (RB); acid (AP) and alkaline (ALP) phosphatases; $\beta$-glycosidase (BG) and urease of soil were assessed. The iCLs systems improved the performance of soil microbiota compared to the conventional system. The rotation of legume and grasses preceded by pasture in iCL A and C, increased the total fungi, bacteria, actinobacteria, enzymatic activity and CBM stocks. This fact contributed to an increased efficiency in environmental performance and added greater sustainability to the system.
\end{abstract}

Keywords: Integrated system. Soil quality. Soil microbiology. Crop rotation.

\section{DINÂMICA DOS ATRIBUTOS MICROBIOLÓGICOS DO SOLO EM SISTEMAS DE INTEGRAÇÃO LAVOURA-PECUÁRIA NO ECÓTONO CERRADO-AMAZÔNIA}

\begin{abstract}
RESUMO - A combinação da produção de grãos e gado em sistemas de integração Lavoura-Pecuária (iLPs) oferece a oportunidade de aumentar a produtividade, melhorar os atributos do solo e a sustentabilidade do sistema agropecuário. O objetivo dessa pesquisa foi avaliar o impacto de sete sistemas de uso do solo sobre a sua microbiota. Cinco sistemas de iLPs foram implementados em 2005 em Santa Carmem, MT, Brasil, com diferentes culturas rotativas: iLP A (soja/milho, precedidos por dois anos com pastagem), iLP B (arroz/milho, precedidos por dois anos com soja/milho consorciado com pastagem), iLP C (soja/milho, precedidos por três anos com pastagem), iLP D (pastagem/milho, precedidos por cinco soja/milho ou milheto consorciados com pastagem) e iLP E (pastagem/milho, precedidos por três anos com pastagem). Estes foram comparados com dois sistemas: um sistema convencional de sucessão soja/milho (CC) e a mata nativa (NF). Os solos dos sete sistemas foram coletados (0,00-0,20 m) e avaliados por dois anos (2012 e 2013) quanto a dinâmica das populações de fungos, bactérias, actinobactérias e micro-organismos celulolíticos; estoques de carbono da biomassa microbiana $(\mathrm{CBM})$; quociente metabólico $\left(q \mathrm{CO}_{2}\right)$; respiração basal $(\mathrm{RB})$; fosfatases ácida $(\mathrm{AP}) \mathrm{e}$ alcalina (ALP); $\beta$-glicosidase (BG) e urease do solo. Os sistemas de iLPs melhoraram o desempenho da microbiota do solo em comparação ao sistema convencional. A rotação de leguminosas e gramíneas precedidas por pastagem nas iLPs A e C, promoveu aumentos nos: totais de fungos, bactérias, actinobactérias, atividade enzimática e estoques de CBM. Esse fato contribuiu para uma maior eficiência no desempenho ambiental e agregou maior sustentabilidade ao sistema.
\end{abstract}

Palavras-chave: Sistemas integrados. Qualidade do solo. Microbiologia do solo. Rotação de culturas.

\footnotetext{
${ }^{*}$ Corresponding author

${ }^{1}$ Received for publication in $04 / 17 / 2018$; accepted in $11 / 05 / 2019$.

Paper extracted from the first author's Master's dissertation.

${ }^{2}$ Tropical Agriculture Post Graduation, Universidade Federal de Mato Grosso, Cuiabá, MT, Brazil; heirianemartins@hotmail.com ORCID: 0000-0002-3729-9427, amandaagro23@gmail.com - ORCID: 0000-0002-2468-6073, barbara_babu01@hotmail.com - ORCID: 0000-0002-4516-8742.

${ }^{3}$ Universidade Federal de Mato Grosso, Cuiabá, MT, Brazil; suzanna_oliveira@hotmail.com - ORCID: 0000-0002-9726-5501.

${ }^{4}$ Department of Phytotechnics and Plant Health, Universidade Federal de Mato Grosso, Cuiabá, MT, Brazil; camposdts@yahoo.com.br ORCID: 0000-0001-5066-9317.

${ }^{5}$ Empresa Brasileira de Pesquisa Agropecuária - Embrapa Arroz e Feijão, research nucleus in the state of Mato Grosso, Sinop, MT, Brazil; flavio.wruck@embrapa.br-ORCID: 0000-0002-8200-3111.
} 


\section{INTRODUCTION}

Studies point to the need for changes in conventional land use practices, especially in rapidly developing economies such as Brazil, if they are to increase productivity and meet global ecosystem demands (FOLEY et al., 2011; PASTOR et al., 2019).

One possibility for sustainable development of agricultural lands is the implementation of integrated Crop-Livestock systems (iCL), characterized by pasture and crop production in the same area, managed under succession or intercropping rotations, varying according to local edaphoclimatic and economic characteristics (KLUTHCOUSKI; AIDAIR; COBUCCI, 2007). The purpose of this system is to increase the efficiency of use of inputs, soil resources and ensure food security (CHEN et al., 2011; SALTON et al., 2014).

To that purpose, technological reference units (URT) were installed for sustainable production, model validation and the transfer of technology to strategic regions. The URT of iCL installed in 2005 on the Dona Isabina farm in Santa Carmem-MT was the first in Mato Grosso. It was configured with five models of iCL, with variations of grass and leguminous plants species managed in space and time, to meet the needs of this region of the CerradoAmazonia ecotone.

Strategically, the Cerrado-Amazonia ecotone is considered a marginal area for production agriculture, with vulnerable biomes and precipitation patterns. In this scenario, integrated systems are valuable, especially due to breaking disease cycles, and reducing weeds, insect pests and economic risks by diversifying activities (SALTON et al., 2014), and reducing costs in the recovery and renewal of degraded pastures (VILELA et al., 2017).

In order to validate and promote adoption of these systems a series of studies have been conducted. Topics include economic viability (MARTHA JUNIOR; ALVES; CONTINI, 2011), pasture productivity (KLUTHCOUSKI; AIDAIR; COBUCCI, 2007), synergistic strategies for production and environmental quality (LEMAIRE et al., 2014) and changes of soil attributes: (i) chemical (SALTON et al., 2014), (iii) physical (VENDER, 2012) and (iii) biological (ASSIS et al., 2017).

Regarding soil microbiological changes, one issue is the pasture residence time in the system. One study reported that pastures with three years of management under iCL presented more efficient biomass than younger pastures, as it increased CBM and reduced $\mathrm{qCO} 2$. In contrast, areas with degraded pastures contributed with lower $\mathrm{CBM}$ and higher qCO2 (MUNIZ et al., 2011).

However, the different configurations of integrated systems have different dynamics, which makes comparisons and standardization of effects difficult, especially regarding implementation time. Also, little is known about changes in long-term soil microbiological attributes (SILVA et al., 2015). Although the microbial community is sensitive to changes in land use (TABATABAI, 1994), the consolidation of microbiological attributes and their ecosystem services is proportional to the duration of system implementation. For comparison and discrimination purposes, it is recommended to evaluate systems with at least three years duration (ASSIS et al., 2017).

Given this diversity of factors, integrated systems require further long-term studies to evaluate the residual effects promoted by the system in consolidating microbial communities. In this context, the objective of this work was to evaluate the changes in soil microbiota in seven systems, five being iCL systems implemented seven years ago, which differed between their grain and pastures crops established over space and time; and two reference systems: traditional farming and native forest, located in the Cerrado-Amazonia ecotone. The systems were evaluated in order to verify those with the lowest impact on soil microbiological attributes and the maintenance of ecosystem services.

\section{MATERIAL AND METHODS}

\section{Description and history of study areas}

The changes in soil microbiological properties were evaluated during two years, 2012 and 2013, in seven land-use systems: five of which were integrated Crop-Livestock (iCL) systems, installed in 2005 as a Technological Reference Unit (URT) by Embrapa Arroz e Feijão on Dona Isabina

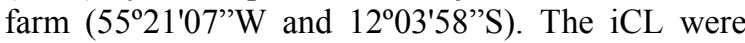
used as alternative systems and additionally two neighboring systems were used as reference, a traditional crop (soybean/maize succession) and a native semi-deciduous forest. The systems are located in the Cerrado-Amazonian ecotone in the municipality of Santa Carmem, Mato Grosso, Brazil (Figure 1).

The area was prepared prior to iCL installation in early 2005, where 100 hectares area previously cultivated with Urochloa brizantha cv. Marandu was divided into five plots of 20 hectares each for the installation of the iCL. Each plot was composed of a system of iCL, identified by iCL A, $\mathrm{B}, \mathrm{C}, \mathrm{D}$ and $\mathrm{E}$, intended for the production of grains, green fertilizer and no-till pasture, with fertilizers applied according to the needs of each crop, following the recommendations of Souza and Lobato (2004) for Cerrado soils. 


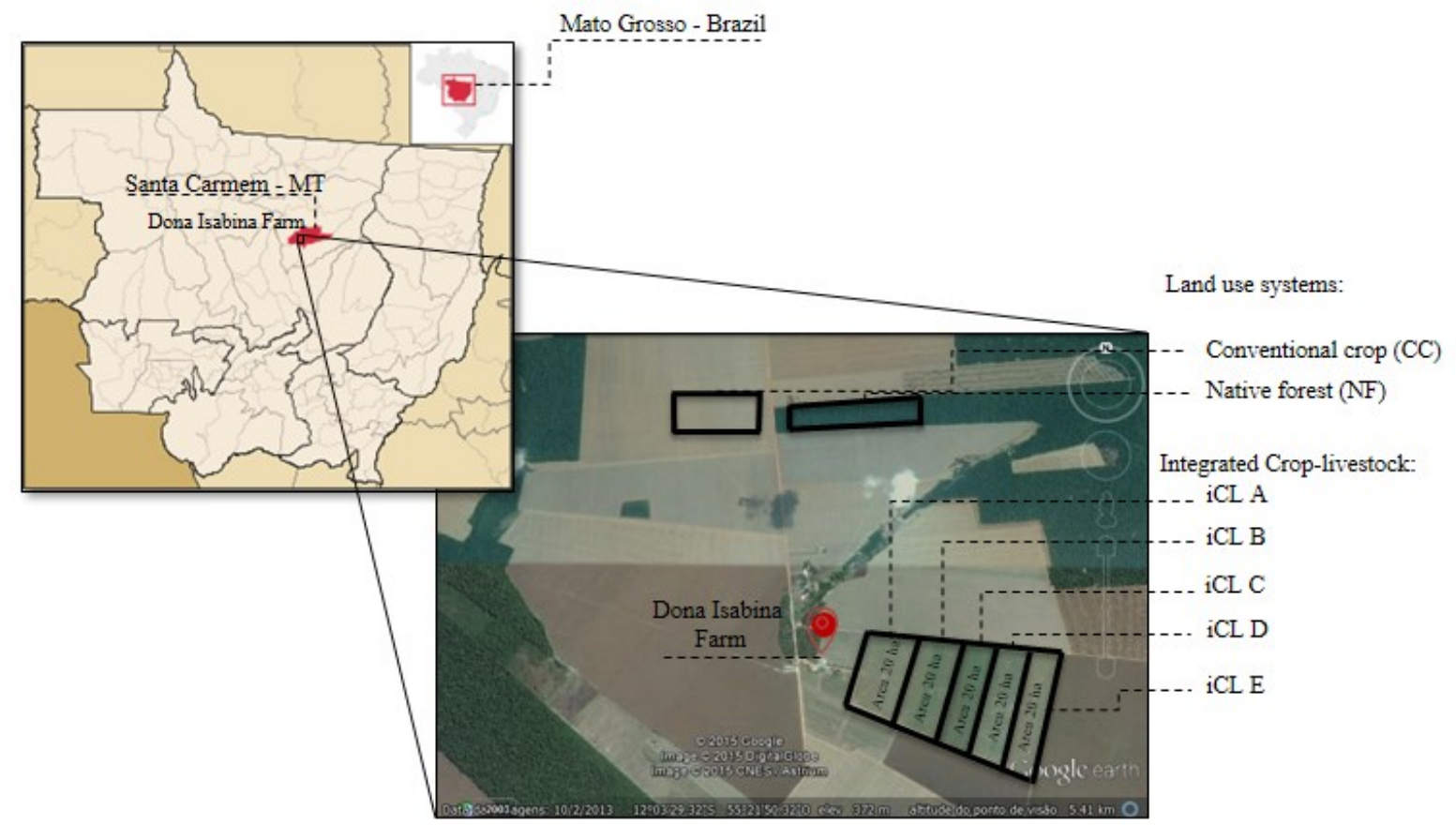

Figure 1. Location of the experiment. Dona Isabina Farm is located in the state of Mato Grosso, within the municipality of Santa Carmem, both highlighted in red. The seven land use areas sampled within the farm: Conventional crop (CC); native forest (NF) and five integrated Crop-Livestock (iCL) systems. These systems had different crops in 2012 and before: iCL A (soybean, preceded by two years with Urochloa brizantha), iCL B (rice/maize), preceded by two years with soybean/maize intercropped with $U$. brizantha, iCL C (soybean/maize, preceded by three years with U. brizantha), iCL D (U. brizanthal maize, preceded by five years of soybean/millet intercropped with $U$. brizantha) and iCL E (U. brizantha/maize, preceded by three years with U. brizantha). Source: Images (C2015 CNES / Astrium, CNES / Spot Image, Digital Globe, Landsat, U.S. Geological Survey, Map Data (C2015 Google.

The differences between the iCL include the crops planted in summer and winter, the duration of a given culture in the systTem and the management (intercropping and/or rotation), as described in Table 1.

The native forest area (NF) was used as an initial soil reference, characterized by semi- deciduous forest with typical Cerrado vegetation, in transition with Amazônia, designated as the CerradoAmazônia ecotone. The traditional model of grain production in Mato Grosso, with crop succession is defined as the conventional crop (CC) system (Table $1)$.

Table 1. History of crops in the seven land use systems from 2005 to 2013, conventional crop (CC), five integration crop -livestock systems (iCL A, B, C, D and E) and native forest (NF), in Santa Carmem, MT, Brazil.

\begin{tabular}{|c|c|c|c|c|c|c|c|c|c|}
\hline Systems & Season & $\begin{array}{c}2005 / \\
2006\end{array}$ & $\begin{array}{c}2006 / \\
2007\end{array}$ & $\begin{array}{c}2007 / \\
2008\end{array}$ & $\begin{array}{c}2008 / \\
2009\end{array}$ & $\begin{array}{c}2009 / \\
2010\end{array}$ & $\begin{array}{c}2010 / \\
2011\end{array}$ & $\begin{array}{c}2011 / \\
2012\end{array}$ & $\begin{array}{c}2012 / \\
2013\end{array}$ \\
\hline $\mathrm{CC}$ & $\begin{array}{l}\text { summer } \\
\text { winter }\end{array}$ & $\begin{array}{c}\text { soybean } \\
\text { maize }\end{array}$ & $\begin{array}{c}\text { soybean } \\
\text { maize }\end{array}$ & $\begin{array}{c}\text { soybean } \\
\text { maize }\end{array}$ & $\begin{array}{c}\text { soybean } \\
\text { maize }\end{array}$ & $\begin{array}{c}\text { soybean } \\
\text { maize }\end{array}$ & $\begin{array}{c}\text { soybean } \\
\text { maize }\end{array}$ & $\begin{array}{c}\text { soybean } \\
\text { maize }\end{array}$ & soybean \\
\hline iCL A & $\begin{array}{l}\text { summer } \\
\text { winter }\end{array}$ & $\begin{array}{c}\text { soybean } \\
\text { sorghum }+ \\
\text { pasture } 1\end{array}$ & $\begin{array}{c}\text { soybean } \\
\text { millet }+ \\
\text { pasture } 1\end{array}$ & $\begin{array}{c}\text { rice } \\
\text { sorghum + } \\
\text { pasture } 1\end{array}$ & $\begin{array}{c}\text { soybean } \\
\text { maize }+ \\
\text { pasture } 2\end{array}$ & $\begin{array}{l}\text { pasture } 2 \\
\text { pasture } 2\end{array}$ & $\begin{array}{l}\text { pasture } 2 \\
\text { pasture } 2\end{array}$ & $\begin{array}{l}\text { soybean } \\
\text { maize }\end{array}$ & soybean \\
\hline iCL B & $\begin{array}{l}\text { summer } \\
\text { winter }\end{array}$ & $\begin{array}{l}\text { soybean } \\
\text { pasture } 2\end{array}$ & $\begin{array}{l}\text { pasture } 2 \\
\text { pasture } 2\end{array}$ & $\begin{array}{l}\text { pasture } 2 \\
\text { pasture } 2\end{array}$ & $\begin{array}{l}\text { rice } \\
\text { bean }\end{array}$ & $\begin{array}{c}\text { soybean } \\
\text { maize+ } \\
\text { pasture } 1\end{array}$ & $\begin{array}{c}\text { soybean } \\
\text { crotalaria+ } \\
\text { pasture } 1\end{array}$ & $\begin{array}{l}\text { rice } \\
\text { maize }\end{array}$ & soybean \\
\hline iCL C & $\begin{array}{l}\text { summer } \\
\text { winter }\end{array}$ & $\begin{array}{c}\text { rice } \\
\text { pasture } 2\end{array}$ & $\begin{array}{l}\text { pasture } 2 \\
\text { pasture } 2\end{array}$ & $\begin{array}{l}\text { pasture } 2 \\
\text { pasture } 2\end{array}$ & $\begin{array}{l}\text { pasture } 2 \\
\text { pasture } 2\end{array}$ & $\begin{array}{c}\text { rice } \\
\text { pasture } 2\end{array}$ & $\begin{array}{l}\text { soybean } \\
\text { maize }+ \\
\text { pasture } 1\end{array}$ & $\begin{array}{l}\text { soybean } \\
\text { maize }\end{array}$ & soybean \\
\hline
\end{tabular}

Rotated or intercropped crops (+). Pasture 1: Urochloa ruziziensis, Pasture 2: Urochloa brizantha (cv. marandu), Pasture 3: Urochloa brizantha (cv. piatã), soybean (Glycine max) early cultivar, maize (Zea mays), sorghum (Sorghum bicolor), millet (Pennisetum glaucum), rice (Oryza sativa); Crotalaria spectabilis and legume: Stylosanthes spp. (cv. estilosantes Campo Grande).

Rev. Caatinga, Mossoró, v. 33, n. 1, p. 09 - 20, jan. - mar., 2020 
H. M. SOUSA et al.

Table 1. Continuation

\begin{tabular}{|c|c|c|c|c|c|c|c|c|c|}
\hline Systems & Season & $\begin{array}{c}2005 / \\
2006\end{array}$ & $\begin{array}{c}2006 / \\
2007\end{array}$ & $\begin{array}{c}2007 / \\
2008\end{array}$ & $\begin{array}{c}2008 / \\
2009\end{array}$ & $\begin{array}{c}2009 / \\
2010\end{array}$ & $\begin{array}{c}2010 / \\
2011 \\
\end{array}$ & $\begin{array}{c}2011 / \\
2012\end{array}$ & $\begin{array}{c}2012 / \\
2013 \\
\end{array}$ \\
\hline \multirow[b]{2}{*}{ iCL D } & summer & soybean & soybean & soybean & soybean & soybean & rice & pasture 3 & soybean \\
\hline & winter & $\begin{array}{c}\text { maize }+ \\
\text { pasture } 1\end{array}$ & $\begin{array}{c}\text { sorgo+ } \\
\text { pasture } 1\end{array}$ & $\begin{array}{c}\text { millet }+ \\
\text { pasture } 1\end{array}$ & $\begin{array}{c}\text { millet }+ \\
\text { pasture } 1\end{array}$ & $\begin{array}{l}\text { millet }+ \\
\text { pasture } 1\end{array}$ & $\begin{array}{l}\text { pasture } 3 \\
+ \text { legume }\end{array}$ & maize & \\
\hline \multirow[b]{2}{*}{ iCL E } & summer & soybean & rice & soybean & soybean & pasture 3 & pasture 3 & pasture 3 & soybean \\
\hline & winter & $\begin{array}{c}\text { millet }+ \\
\text { pasture } 1\end{array}$ & $\begin{array}{c}\text { maize }+ \\
\text { pasture } 3\end{array}$ & $\begin{array}{c}\text { maize }+ \\
\text { pasture } 3\end{array}$ & pasture 3 & pasture 3 & pasture 3 & maize & \\
\hline $\mathrm{NF}$ & $\begin{array}{c}\text { summer } \\
\text { winter }\end{array}$ & forest & forest & forest & forest & forest & forest & forest & forest \\
\hline
\end{tabular}

Rotated or intercropped crops (+). Pasture 1: Urochloa ruziziensis, Pasture 2: Urochloa brizantha (cv. marandu), Pasture 3: Urochloa brizantha (cv. piatã), soybean (Glycine max) early cultivar, maize (Zea mays), sorghum (Sorghum bicolor), millet (Pennisetum glaucum), rice (Oryza sativa); Crotalaria spectabilis and legume: Stylosanthes spp. (cv. estilosantes Campo Grande).

\section{Climate characterization and soil collection}

The region's climate is warm and humid tropical type Aw, according to the Köppen classification. The mean annual temperature is $24^{\circ} \mathrm{C}$, with vegetation characterized by semi-deciduous forest, with flat topography and mean altitude of 435 $\mathrm{m}$. The mean annual rainfall is $2000 \mathrm{~mm}$ and is concentrated between October and April, with the highest value in January, coincident with soil sampling, as shown in Figure 2. The climatogram was generated with data collected from an automatic station $30 \mathrm{~km}$ from the experimental area, provided by the Instituto Nacional de Meteorologia - INMET.

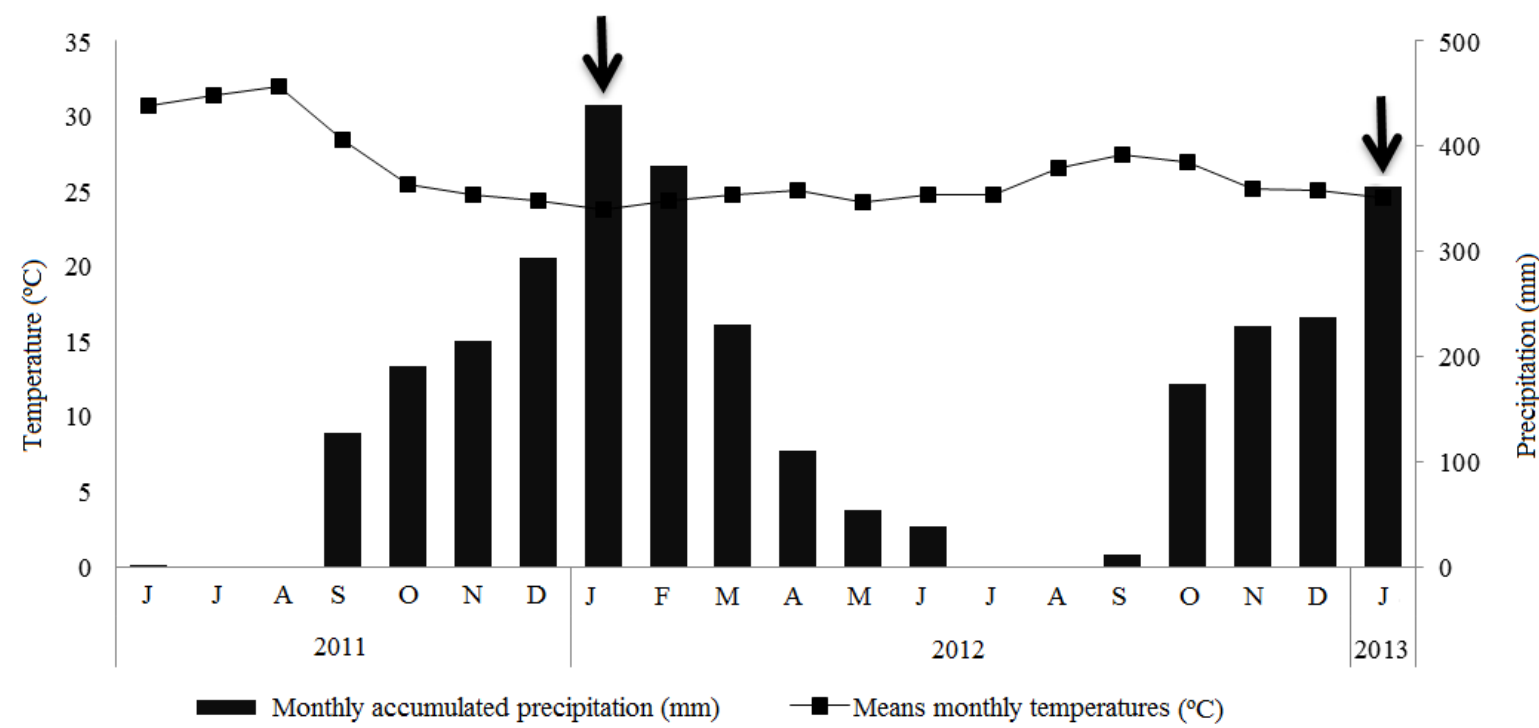

Figure 2. Climatogram with monthly means of temperature and cumulative monthly precipitation from June 2011 to January 2013, arrows indicate the months of soil sampling (January 2012 and 2013). Source: Data provided by INMET (Instituto Nacional de Meteorologia).

The soil was classified as Latossolo Vermelho-Amarelo distrófico (Oxisol) by Santos (2005), with clayey texture. Nutrient and physical attributes were determined in the $0.00-0.20 \mathrm{~m}$ layer, and are described in Table 2.

Deformed soil samples were collected with the aid of a Dutch auger in the $0.00-0.20 \mathrm{~m}$ soil layer
(A horizon). In each system five samples were collected composed of four subsamples, totaling 20 sampling points in each system. The collected soil was homogenized, sieved ( $2 \mathrm{~mm}$ mesh) and stored at $4^{\circ} \mathrm{C}$ until the microbiological analysis was completed. 
H. M. SOUSA et al.

Table 2. Physical and chemical properties of the 0.00-0.20 m layer of an Oxisol soil, managed under seven systems, conventional crop (C/C), five integrated Crop-Livestock systems (iCL A, B, C, D and E) and native forest (NF), sampled in 2012, in Santa Carmem, MT, Brazil.

\begin{tabular}{lccccccc}
\hline Physical and chemical attributes & CC & iCL A & iCL B & iCL C & iCL D & iCL E & NF \\
\hline Macroporosity, 0,10-0,20 ${\mathrm{m}\left(\mathrm{m}^{3} \mathrm{~m}^{3}\right)^{*}}^{3}$ & - & 0.10 & 0.09 & 0.09 & 0.09 & 0.09 & 0.12 \\
Microporosity, 0,10-0,20 $\left.\mathrm{m}^{3} \mathrm{~m}^{3}\right)^{*}$ & - & 0.34 & 0.34 & 0.34 & 0.35 & 0.35 & 0.32 \\
Bulk density, 0,10-0,20 $\left(\mathrm{g} \mathrm{cm}^{3}\right)^{*}$ & - & 1.13 & 1.17 & 1.15 & 1.15 & 1.16 & 1.14 \\
Clay $\left(\mathrm{g} \mathrm{kg}^{-1}\right)$ & 501 & 492 & 555 & 568 & 580 & 589 & 451 \\
Silt $\left(\mathrm{g} \mathrm{kg}^{-1}\right)$ & 100 & 88 & 25 & 50 & 50 & 63 & 100 \\
Sand $\left(\mathrm{g} \mathrm{kg}^{-1}\right)$ & 399 & 420 & 420 & 382 & 370 & 348 & 449 \\
Organic matter $\left(\mathrm{g} \mathrm{kg}^{-1}\right)$ & 18.0 & 21.9 & 16.3 & 16.8 & 16.5 & 18.7 & 24.8 \\
pH $\left(\mathrm{CaCl}_{2}\right)$ & 4.9 & 4.6 & 4.6 & 4.6 & 4.8 & 4.6 & 3.8 \\
$\mathrm{P}\left(\mathrm{mg} \mathrm{dm}^{3}\right)$ by Mehlich1 & 1.93 & 4.59 & 1.57 & 2.21 & 2.29 & 2.07 & 0.06 \\
$\mathrm{~K}\left(\mathrm{mg} \mathrm{dm}^{3}\right)$ by Mehlich1 & 60.0 & 61.0 & 65.0 & 73.0 & 153.0 & 32.0 & 23.0 \\
\left.${\mathrm{CEC}\left(\mathrm{cmol}_{\mathrm{c}} \mathrm{dm}\right.}^{3}\right)$ & 7.87 & 8.31 & 6.8 & 6.94 & 6.99 & 6.73 & 8.51 \\
Base saturation $(\%)$ & 39.0 & 37.4 & 27.9 & 36.6 & 39.9 & 34.6 & 4.8 \\
Aluminum saturation $(\%)$ & 4.7 & 6.0 & 11.6 & 7.3 & 3.5 & 6.0 & 75.3 \\
\hline
\end{tabular}

CEC: Cation exchange capacity at $\mathrm{pH} 7.0$, Base saturation: $\mathrm{K}^{+}, \mathrm{Ca}^{2+}, \mathrm{Mg}^{2+}$. ${ }^{*}$ Source: Vender, (2012).

\section{Microbiological Analyses}

The microbiological attributes of the soil assessed were carbon microbial biomass (CBM), soil basal respiration $(\mathrm{RB})$, metabolic quotient $\left(q \mathrm{CO}_{2}\right)$, acid phosphatase (AP), alkaline phosphatase (ALP), $\beta$-glycosidase $(\mathrm{BG})$, urease and soil cultivable microorganisms: bacteria (Bac), fungi (Fung), actinobacteria (Actino) and microorganisms with cellulolytic activity (MC).

The CBM and RB were determined using the fumigation-incubation method (JENKINSON; POWLSON, 1976). Calculations were performed according to Alef and Nannipieri (1995), using an incubation efficiency correction factor of 0.45 (tropical soils), quantified by the evolution of $\mathrm{CO}_{2}$ for five days of aerobic incubation. The $q \mathrm{CO}_{2}$ was determined by the ratio of soil RB per CBM unit (ANDERSON; DOMSCH, 1990). All fumigated and non-fumigated samples were analyzed in triplicate.

The activity of the enzymes AP, ALP and BG were quantified based on the colorimetric determination of $p$-nitrophenol produced per $\mathrm{h}^{-1} \mathrm{~g}^{-1}$ dry soil ${ }^{-1}$, after incubation of the soil with substrates specific to a given enzyme. The substrate used was $p$ -nitrophenyl phosphate in buffered solution at $\mathrm{pH} 6.5$ for $\mathrm{AP}$ and $\mathrm{pH} 11$ for ALP, and $p$-nitrophenyl $\beta$-DGlucoside for BG (TABATABAI, 1994). Urease was also determined by ammonia-quantified colorimetry $\left(\mathrm{NH}_{4}-\mathrm{N}\right)$ produced per $\mathrm{h}^{-1} \mathrm{~g}^{-1}$ dry soil ${ }^{-1}$ by incubating soil samples with urea solution (KANDELER; GERBER, 1988). All enzyme analyses were performed in triplicate.

The quantification of the cultivable soil microorganisms, such as fungi, bacteria, actinobacteria and cellulase activity (cellulolytic microorganisms) was performed following the method of serial dilution followed by spread plate on petri dishes using mediums of solid and selective cultures (WOLLUM, 1982). For bacteria, nutrient agar was used, whereas for fungi, potato dextrose and agar (PDA). For actinobacteria, soil extract was used (PRAMER; SCHMIDT, 1964) and for cellulolytic activity microorganisms, carboxymethyl cellulose (CMC) soil extract was used (WOOD, 1980).

The entire serial dilution procedure followed by inoculation was performed in a laminar flow chamber with the aid of a Bunsen nozzle and automatic pipettes. The plates were inoculated in triplicate followed by incubation in biological oxygen demand (BOD at $\pm 28^{\circ} \mathrm{C}$ dark) and readings were taken after $24 \mathrm{~h}$ for bacteria, $48 \mathrm{~h}$ for fungi, 7 days for actinobacteria and 10 days for cellulolytics. For the latter, the CMC degradation halo was revealed by congo red staining and subsequent quantification of positive colony forming units (CFU). Results were expressed in CFU g ${ }^{-1}$ dry soil ${ }^{-1}$.

\section{Statistical Analysis}

The structure of the interrelationships between microbiological and climatic variables (precipitation, humidity and mean temperature), and the discrimination of land use systems was assessed by principal component analysis (PCA). All variables were normalized for PCA. The PCA biplot was generated from the first two components and Pearson correlations were performed between the variables using $\mathrm{R}$ software version 3.6.1.

The effects of iCL systems on changes in microbiological attributes were evaluated by analysis of variance (ANOVA), with significant differences compared by Tukey test $(p<0.05)$ using IBM $^{\circledR}$ 
SPSS ${ }^{\circledR}$ Statistics software (version 23, SPSS, Inc., Chicago, IL, USA).

\section{RESULTS AND DISCUSSION}

The microbiological attributes differed between the iCL systems and sampled years. The PCA applied to the microbiological and climatic variables efficiently discriminated the land use systems and allowed the identification of the properties that had the greatest influence. The cumulative variability for the first two components was $74.3 \%$ of the total variance, with $56.9 \%$ and $17.4 \%$ corresponding to components 1 and 2, respectively (Figure 3 ).

Three groups were formed, two groups in 2013 and one group in 2012. The systems iCL A, iCL C and NF (2013) were integrated in the first group, the second group consisted of the systems iCL B, iCL D, iCL E and CC (2013), and the third group was formed by all systems sampled in 2012, this year in turn was less efficient in discriminating systems (Figure 3).

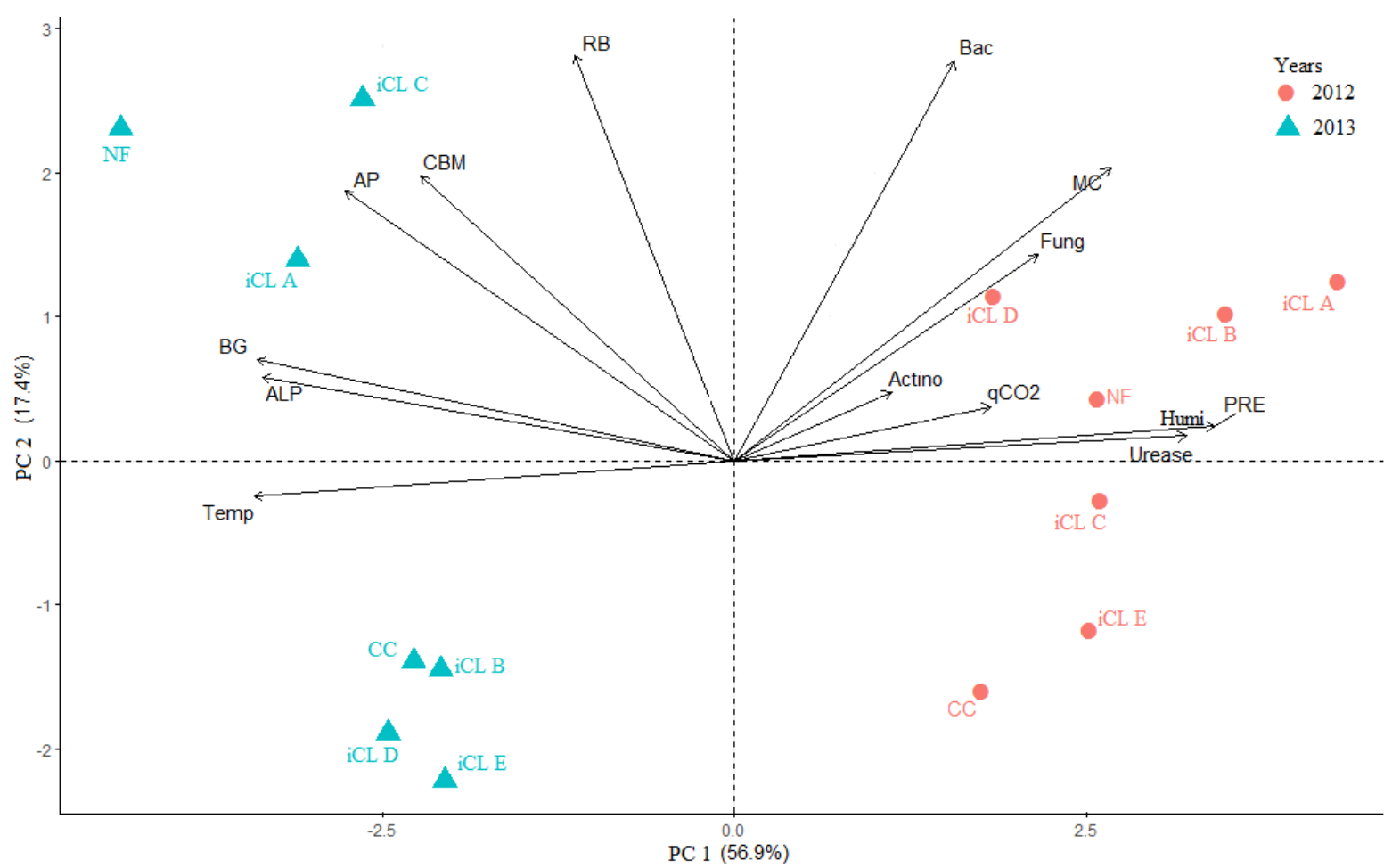

Figure 3. Biplot of the Principal Component Analysis (PCA) of soil microbiological attributes including soil cultivable microorganisms (Bac: bacteria; Fung: Fungi; Actin: actinobacteria; MC: cellulolytics), soil enzymatic activity (BG: $\beta$ glycosidase; AP: Acid Phosphatase; ALP: Alkaline Phosphatase; urease), Microbial Biomass Carbon (CBM), soil basal respiration (RB), metabolic quotient $\left(q \mathrm{CO}_{2}\right)$, precipitation (PRE), humidity (Humi), and mean temperature (Temp).

The variables Bac, MC, Fung, Actino, $q \mathrm{CO}_{2}$ and urease discriminated the systems in 2012 from the groups in 2013, while CBM, RB, AP, BG and ALP discriminated the $\mathrm{iCL} A, \mathrm{iCL} C$ and NF systems in 2013 from the CC, iCL systems. B, iCL D and $\mathrm{iCL} \mathrm{E}$ in 2013.

Climatic factors correlated strongly $(>0.95)$ with PC 1 (Table 3), and had a strong influence on system discrimination. The segregation of the systems in 2013 highlights the changes in microbiological attributes caused by differences in soil use and management. This year was influenced by neither El Niño nor La Niña events, while in 2012 the largest rainfall accumulation was influenced by the end of La Niña (MARCUZZO; OLIVEIRA; CARDOSO, 2012).

The ENSO cycle exerts direct influences on climatic conditions causing extreme events, marked by sudden rainfall variations and consequent impacts on the environment (MARCUZZO; OLIVEIRA; CARDOSO, 2012).

The precipitation is also accompanied by variations in temperature and humidity of the environment that directly affect the cellular metabolism, activity and structure of soil microbial communities (BLAGODATSKAYA; KUZYAKOV, 2013). Therefore, excess precipitation in 2012 may have prevented any detection of change in the compilation of microbiological variables, while in 2013 when the precipitation was lower, land use systems had a greater influence on this dynamic and segregated.

This segregation of systems in 2013, indicated similarities between $\mathrm{iCL} \mathrm{C}$ and $\mathrm{iCL}$ A with the native forest reference system (NF), indicating the contribution of integrated systems in improving and/or maintaining microbiological attributes. The diversification of plant species in these systems 
(soybean, sorghum, maize, millet and grass) combined with no-tillage management stimulated microbial activity and increased soil enzymatic activity (SALTON et al., 2014), increasing ecosystem services and soil resilience (LEMAIRE et al., 2014).

The variables temperature (Temp), $\beta$ glycosidase (BG), alkaline phosphatase (ALP), acid phosphatase (AP) and microbial biomass carbon $(\mathrm{CBM})$ showed strong $(>0.60)$ negative correlations with PC 1 whereas positive correlations were observed for the variables: precipitation (PRE), humidity (Humi), urease, cellulolytic activity (MC) and fungi (Fung). While basal respiration (BR) and bacteria (Bac) variables were strongly positively correlated with principal component 2 (Table 3 ).

Table 3. Correlations between microbiological and climate variables associated with the first and second components (PC 1 and 2) of the Principal Component Analysis.

\begin{tabular}{|c|c|c|c|c|c|c|c|c|c|c|c|c|c|c|}
\hline & Temp & PRE & Humi & BG & Urease & ALP & $\mathrm{MC}$ & RB & CBM & $\mathrm{Bac}$ & $\mathrm{AP}$ & Actino & $q \mathrm{CO}_{2}$ & Fung \\
\hline PC 1 & -0.96 & 0.96 & 0.96 & -0.95 & 0.90 & -0.94 & 0.75 & -0.32 & -0.62 & 0.43 & -0.77 & 0.31 & 0.51 & 0.60 \\
\hline PC 2 & -0.07 & 0.07 & 0.07 & 0.20 & 0.05 & 0.16 & 0.57 & 0.79 & 0.56 & 0.78 & 0.53 & 0.13 & 0.11 & 0.40 \\
\hline
\end{tabular}

Variables are mean temperature (Temp), precipitation (PRE), humidity (Humi), soil enzymatic activity (BG: $\beta$ Glycosidase; urease; ALP: Alkaline Phosphatase; AP: Acid Phosphatase), cultivable soil microorganisms (Bac: bacteria; Fung: Fungi; Actin: actinobacteria; MC: cellulolytics), soil basal respiration (RB), microbial biomass carbon (CBM), and metabolic quotient $\left(q \mathrm{CO}_{2}\right)$.

High correlations $(>0.65)$ between climatic variables and enzyme activity (BG, AP, ALP and Urease) reinforce the effects of climate action on soil microbiological attributes. BG (0.94), AP (0.68) and ALP (0.91) showed common attributes including positive correlations with temperature, and negative correlations with precipitation and humidity $(-0.94$; 0.68 and -0.91 , respectively). Urease also showed high (but contrary to BG, AP and ALP) negative correlations with temperature (-0.89) and positive correlations with humidity and precipitation (0.89) (Table 4).

The microbiological attributes were also strongly correlated, in particular BG with other enzymes, CBM with AP (0.69), and cellulolytic activity with Bac (0.78) and Fung (0.67) (Table 4 ).

Table 4. Correlation coefficients (r) between soil microbiological and climatic variables, in soil samples collected in the 0.00-0.20 m layer, in seven land use systems in Santa Carmem, MT, Brazil.

\begin{tabular}{|c|c|c|c|c|c|c|c|c|c|c|c|c|c|c|}
\hline & $\mathrm{Bac}$ & Fung & Actino & $\mathrm{MC}$ & BG & $\mathrm{AP}$ & ALP & Urease & CBM & $\mathrm{RB}$ & $\mathrm{qCO}_{2}$ & PRE & Humi & Temp \\
\hline Fung & $0.55^{* * *}$ & 1 & & & & & & & & & & & & \\
\hline $\mathrm{MC}$ & $0.78 * * *$ & $0.67 * * *$ & 0.32 & 1 & & & & & & & & & & \\
\hline BG & -0.29 & -0.38 & -0.18 & $-0.60 * * *$ & 1 & & & & & & & & & \\
\hline ALP & -0.27 & -0.38 & -0.33 & -0.59 & $0.96 * * *$ & $0.84^{* *}$ & 1 & & & & & & & \\
\hline Urease & $0.41 * *$ & $0.49^{* *}$ & 0.11 & $0.59 * * *$ & $-0.81 * * *$ & $-0.57 * * *$ & $-0.81 * * *$ & 1 & & & & & & \\
\hline CBM & 0.17 & -0.30 & -0.24 & -0.15 & $0.59 * * *$ & $0.69 * * *$ & $0.56^{* * *}$ & $-0.58 * * *$ & 1 & & & & & \\
\hline $\mathrm{RB}$ & 0.27 & -0.01 & 0.05 & 0.17 & $0.46^{* *}$ & $0.65^{* * *}$ & 0.37 & -0.16 & $0.63^{* * *}$ & 1 & & & & \\
\hline Temp & $-0.47 * *$ & $-0.46^{* *}$ & -0.15 & $-0.73 * * *$ & $0.94 * * *$ & $0.68 * * *$ & $0.91 * * *$ & $-0.89 * * *$ & $0.46^{* *}$ & 0.20 & -0.34 & $-1.00 * * *$ & $-1.00 * * *$ & 1 \\
\hline
\end{tabular}

Variables are soil cultivable microorganisms (Bac: bacteria; Fung: Fungi; Actin: actinobacteria; MC: cellulolytics), soil enzymatic activity (BG: $\beta$-glycosidase; AP: Acid Phosphatase; ALP: Alkaline Phosphatase; urease), microbial biomass carbon $(\mathrm{CBM})$, soil basal respiration (RB), metabolic quotient $\left(q \mathrm{CO}_{2}\right)$, precipitation (PRE), humidity (Humi), and mean temperature (Temp). The value of $\mathrm{r}$ followed by $* *$ and $* * *$ is significant at 1 and $0.1 \%$ probability, respectively. Values in bold correspond to correlations $>0.60$ negative or positive.

The strong positive correlations of BG, AP, and ALP enzymes with temperature and negative correlations with precipitation and humidity, suggest higher activity of these enzymes in environments with higher temperatures, and lower precipitation and humidity. On the other hand, urease activity was higher under climatic conditions with lower temperature, and higher humidity and precipitation. These facts corroborate the higher activity of the enzymes BG, AP, and ALP in 2013, in contrast to urease that had highest activity in 2012 (Table 5). 
The iCL A, iCL $\mathrm{C}$ and NF systems provided more $\mathrm{CBM}$ and $\mathrm{RB}$ and had higher $\mathrm{BG}, \mathrm{AP}$, and ALP enzymatic activity compared to $\mathrm{CC}, \mathrm{iCL} \mathrm{B}, \mathrm{iCL}$ $\mathrm{D}$ and iCL $\mathrm{E}$ in 2013. Soil under integrated systems (iCL A and C) contributed with increments of over
$50 \%$ of $\mathrm{CBM}$ compared to conventional crop practices $(\mathrm{CC})$ in 2013. The $\mathrm{RB}$ and $q \mathrm{CO}_{2}$ were higher in iCL A and enzymes (AP, ALP and BG) had higher soil activity under native vegetation (NF) (Table 5).

Table 5. Properties of microbial biomass and soil enzymatic activity managed under seven systems: conventional crop (soybean/maize succession) (CC), five integrated crop-livestock systems (iCL A, B, C, D and E) and native forest (NF). Soil samples collected in the 0.00-0.20 m layer, in 2012 and 2013, in Santa Carmem, MT, Brazil.

\begin{tabular}{|c|c|c|c|c|c|c|c|}
\hline \multirow{2}{*}{$\begin{array}{l}\text { Biological } \\
\text { properties }\end{array}$} & \multicolumn{7}{|c|}{ Land use systems } \\
\hline & $\mathrm{CC}$ & iCL A & iCL B & iCL C & iCL D & iCL E & NF \\
\hline CBM & $28913 \mathrm{~b}$ & $4724 \mathrm{~s}$ & $20409 \mathrm{bc}$ & $8603 \mathrm{hr}$ & $77660 \Omega$ & & $17053 \mathrm{hr}$ \\
\hline $\mathrm{RB}$ & $204.09 \mathrm{ab}$ & $255.97 \mathrm{a}$ & $193.04 \mathrm{ab}$ & $\begin{array}{r}215.15 \mathrm{ab} \\
2150\end{array}$ & $214.30 \mathrm{ab}$ & $162.42 \mathrm{~b}$ & $241.51 \mathrm{ab}$ \\
\hline$q \mathrm{CO}_{2}$ & $0.71 \mathrm{c}$ & $5.82 \mathrm{a}$ & $0.94 \mathrm{c}$ & $2.62 \mathrm{~b}$ & $0.28 \mathrm{c}$ & $1.34 \mathrm{c}$ & $1.44 \mathrm{c}$ \\
\hline $\mathrm{BG}$ & 114.05 & 116.39 & 123.94 & 123.16 & 108.33 & 110.67 & 127.06 \\
\hline $\mathrm{AP}$ & $131.59 \mathrm{ab}$ & $117.79 \mathrm{~b}$ & $100.02 \mathrm{~b}$ & $107.98 \mathrm{~b}$ & $127.91 \mathrm{~b}$ & $80.09 \mathrm{~b}$ & $184.00 \mathrm{a}$ \\
\hline ALP & 60.78 & 46.68 & 171.74 & 168.06 & 97.26 & 77.03 & 62.31 \\
\hline Urease & $435.23 \mathrm{a}$ & $440.47 \mathrm{a}$ & $409.02 \mathrm{a}$ & $361.85 \mathrm{~b}$ & $261.22 \mathrm{c}$ & $346.13 \mathrm{~b}$ & $419.50 \mathrm{a}$ \\
\hline & & & & --2013--- & & & ----- \\
\hline CBM & $311.99 \mathrm{c}$ & $761.80 \mathrm{a}$ & $266.63 \mathrm{bc}$ & $607.68 \mathrm{a}$ & $476.28 \mathrm{~b}$ & $221.33 \mathrm{c}$ & $778.76 \mathrm{a}$ \\
\hline $\mathrm{RB}$ & $101.06 \mathrm{c}$ & $405.25 \mathrm{a}$ & $63.26 \mathrm{c}$ & $351.63 \mathrm{a}$ & $134.19 \mathrm{c}$ & $246.53 \mathrm{~b}$ & $417.71 \mathrm{a}$ \\
\hline$q \mathrm{CO}_{2}$ & 0.44 & 0.53 & 0.28 & 0.58 & 0.28 & 1.89 & 0.54 \\
\hline BG & $225.05 \mathrm{~cd}$ & $281.20 \mathrm{~b}$ & $239.91 \mathrm{c}$ & $275.10 \mathrm{~b}$ & $216.06 \mathrm{~d}$ & $236.39 \mathrm{~cd}$ & $318.46 \mathrm{a}$ \\
\hline $\mathrm{AP}$ & $284.03 \mathrm{c}$ & $322.42 \mathrm{c}$ & $221.49 \mathrm{~d}$ & $399.56 \mathrm{~b}$ & $140.34 \mathrm{e}$ & $156.88 \mathrm{e}$ & $500.97 \mathrm{a}$ \\
\hline ALP & $647.97 \mathrm{c}$ & $632.05 \mathrm{c}$ & $702.99 \mathrm{bc}$ & $837.25 \mathrm{~b}$ & $675.64 \mathrm{c}$ & $614.34 \mathrm{c}$ & $1195.35 \mathrm{a}$ \\
\hline Urease & 213.38 & 203.78 & 202.76 & 203.31 & 200.81 & 203.42 & 220.57 \\
\hline
\end{tabular}

CBM: Microbial Biomass Carbon in $\mu \mathrm{g} \mathrm{C} \mathrm{g}^{-1}$ dry soil ${ }^{-1}$; RB: Basal respiration of soil in $\mu \mathrm{g} \mathrm{C}-\mathrm{CO}_{2} \mathrm{~g}^{-1}$ dry soil $^{-1}$ in 5 days; $q \mathrm{CO}_{2}$ : metabolic quotient in $\mu \mathrm{g} \mathrm{CO}_{2} \mu \mathrm{g} \mathrm{C}$ mic day ${ }^{-1}$; BG: $\beta$-glycosidase, AP: Acid Phosphatase, ALP: Alkaline Phosphatase, the last three enzymes in $\mu \mathrm{g} p$-nitrophenol $\mathrm{h}^{-1} \mathrm{~g}^{-1}$ dry soil ${ }^{-1}$ and urease $\mu \mathrm{g} \mathrm{NH}_{4}-\mathrm{N} \mathrm{h}^{-1} \mathrm{~g}$ dry soil $^{-1}$. Means followed by different letters in the same line indicate significant differences between land use systems (Tukey test; $\mathrm{p}<0.05$ ); when absent, there was no significance.

The high stock of CBM presented by iCL D in $2012\left(776.69 \mu \mathrm{g} \mathrm{C} \mathrm{g}{ }^{-1}\right.$ dry soil $\left.{ }^{-1}\right)$, is due to the diversity of annual crops planted in this area. From 2005 to 2013 , this system always maintained a grain culture in summer (soybean or rice), followed by two intercropping grasses (maize, sorghum or millet + pasture). Unlike other iCL modules, this module (iCL D) was planned to maintain crop and livestock activity in the same agricultural year. The presence of three crops, varying between legumes and grasses, provided greater soil $\mathrm{C}$ inputs through the amount and diversity of necromass and exudates released into the rhizosphere (CHÁVEZ et al., 2011).

Additionally, increases in $\mathrm{CBM}$ stocks in $\mathrm{iCL}$ $A$ and $C$ in 2013 were also attributed to the diversification between grasses and legumes. These systems had been managed for two and three continuous years with Urochloa brizantha (cv. Marandu), respectively, with subsequent cultivation by soybean and maize. The fascicular grass root system, concentrated at $0.10 \mathrm{~m}$, results in increased soil C input (ASSIS et al., 2017).

However, although CBM is a measure of soil living microbiota, this characteristic is dynamic and provides little information on biomass quality if evaluated alone (SALTON et al., 2014). Soil RB and $q \mathrm{CO}_{2}$, when evaluated together with $\mathrm{CBM}$, provide information on microbial community efficiency or stress conditions. Systems that promote lower RB and $q \mathrm{CO}_{2}$ are more efficient, because lower $\mathrm{CO}_{2}$ rates lost to $\mathrm{RB}$ result in greater incorporation of CBM, whereas the opposite could suggest stress conditions caused by soil changes (TÓTOLA; CHAER, 2002).

In this context, the increase in CBM in the iCL $\mathrm{A}$ and $\mathrm{C}$ systems was also accompanied by higher soil $\mathrm{RB}$ and $q \mathrm{CO}_{2}$ rates, resulting in less efficient biomass when compared to iCL D, which may be related to a stress condition. These systems were maintained for two consecutive years with the cultivation of Urochloa brizantha (cv. Marandu), subsequently cultivated with soybean, resulting in the increase of $\mathrm{CO}_{2}$ released per unit of biomass promoted by the slow decomposition of the pasture. The Urochloa brizantha decomposition was reported to be slow compared to other pastures, due to its high $\mathrm{C} / \mathrm{N}$ ratio (40) (PARIZ et al., 2008). This reflects the higher energy expenditure of the microbiota in the form of $\mathrm{CO}_{2}$ release from the decomposition of more lignified products, until their incorporation (SANTOS, 2005).

In contrast, iCL D soil microbial biomass was 
more efficient and stable due to lower $q \mathrm{CO}_{2}(0.28)$ between 2012 and 2013. This is attributed to crop diversity maintained in all agricultural years and the improvements in physical attributes of the soil. The increase in the physical quality of the pores and soil aggregates of iCL D was described by Vender (2012), conferred by the greater accumulation of surface cover and grazing outside the rainy season, which reduces soil compaction. These factors may have contributed to minimize disturbances and stabilize microbial biomass in this soil.

Soil enzymes also play a key role in chemical reactions and soil ecosystem services. In general, they are catalysts and act on decomposition reactions of organic waste and nutrient cycling (TABATABAI, 1994). BG acts in the final stage of the cellulose decomposition process (SILVA et al., 2015), whereas phosphatases act in the mineralization of soil organic P. These are important in Cerrado soils, where the availability of this nutrient is restricted (TABATABAI, 1994; BALOTA et al., 2014). Nitrogen, however, is mediated by urease actions (TABATABAI, 1994).

The high activity of enzymes BG, AP and ALP in the forest soils (NF) is due to the higher contribution of OM $\left(24.8 \mathrm{~g} \mathrm{~kg}^{-1}\right)$ and limitations of $\mathrm{P}$ $\left(0.06 \mathrm{mg} \mathrm{dm}^{3}\right)$. The low availability of $\mathrm{P}$ in the soil induces the production of this enzyme by microorganisms, making it available through mineralization and solubilization processes (GOMIDE; SILVA; SOARES, 2011), which mediated by humic complexes maintains the cycle of nutrients in the soil and the sustainability of this natural ecosystem (TABATABAI, 1994).

In integrated systems, $\mathrm{iCL} A$ and $\mathrm{iCL} C$ contributed more activity from AP and ALP (only in iCL C) compared to the conventional crop. The microbial community established after seven years of system implementation contributed to increase the activity of these enzymes. These extracellular enzymes are secreted by soil microorganisms such as bacteria, fungi and actinobacteria (TABATABAI, 1994).

These microorganisms also contribute to the dynamics of soil organic matter (OM), nutrient cycling, decomposition of $\mathrm{OM}$ and incorporation of carbon into the system (HABIG; SWANEPOEL, 2015). However, they are directly affected by land use (COUTO et al., 2016).

In fact, the population of soil microorganisms (bacteria, fungi and actinobacteria) and cellulolytic activity (MC) were altered by land use systems. The iCL $A$ and iCL $C$ integrated systems showed significantly higher $(p<0.05)$ populations of bacteria, fungi, actinobacteria, and cellulolytic activity than conventional crops (CC) (Figure 4).

The largest populations of microorganisms in iCL $\mathrm{A}$ and iCL $\mathrm{C}$ occurred due to biostimulation of soil microbiota promoted by diversity in and between grasses and legumes. Both systems were maintained with a soybean and maize rotation (2012) preceded by cultivation of $U$. brizantha for 2 years. Maintaining pasture for 2 years in these systems may have added higher root volume, aeration and biomass in the soil, and soybean and maize crops increased the plant diversity in the system. This crop diversity increases the quantity and quality of root exudates released into the soil, attracting and increasing the diversity of microorganisms (COUTO et al., 2016).

The cattle grazing on iCLs A and C during $U$. brizantha cultivation may also have corroborated the increased exudation of organic compounds, as these compounds act as a carbon and energy source for the microbiota, as do cattle manure and urine (CHÁVES et al., 2011)

Contrary to the greater plant diversity of the integrated systems (iCL $\mathrm{A}$, iCL $\mathrm{C}$ and NF), the conventional crop with the continued use of succession between soybean and maize, had lower plant diversity in this system and was accompanied by smaller quantities of all microorganisms in 2012 , and of actinobacteria and cellulolytics in 2013.

These microorganisms are responsible for processes that directly or indirectly influence the productivity and sustainability of terrestrial ecosystems, play a fundamental role in the decomposition of organic compounds and agricultural residues, and act in soil remediation and biogeochemical cycles (BLAGODATSKAYA; KUZYAKOV, 2013). The quantification of cultivable soil microorganisms, despite caveats, helps to understand the processes that occur in the soil (PREVIATI et al., 2012) especially when analyzed in conjunction with other variables such as enzymes and microbial biomass.

Our results show that after seven years the iCL systems improved soil microbiological attributes, showed higher CBM stocks and contributed to a more efficient microbial biomass compared to a conventional crop system. They also increased soil enzymatic activity and microbial populations, especially within the soil of $\mathrm{iCL} A$ and iCL $\mathrm{C}$ as is evident in the PCA.

Therefore, the microbiological quality of the soil conferred by long-term adoption of iCL systems could store carbon in the labile fraction of the soil, increase the efficiency of nutrient use by plants such as carbon, phosphorus and nitrogen, especially when mediated by extracellular enzymes. Other research has shown additional benefits of reducing the vulnerability of agricultural production to climate change and providing greater market flexibility regarding fluctuations in commodity prices (LEMAIRE et al., 2014).

Finally, these qualities promoted by the adoption of integrated systems could answer the two major demands of Brazilian agriculture, the recovery of degraded pastures and the growing demand for food in accordance with food security (LEMAIRE et al., 2014). 

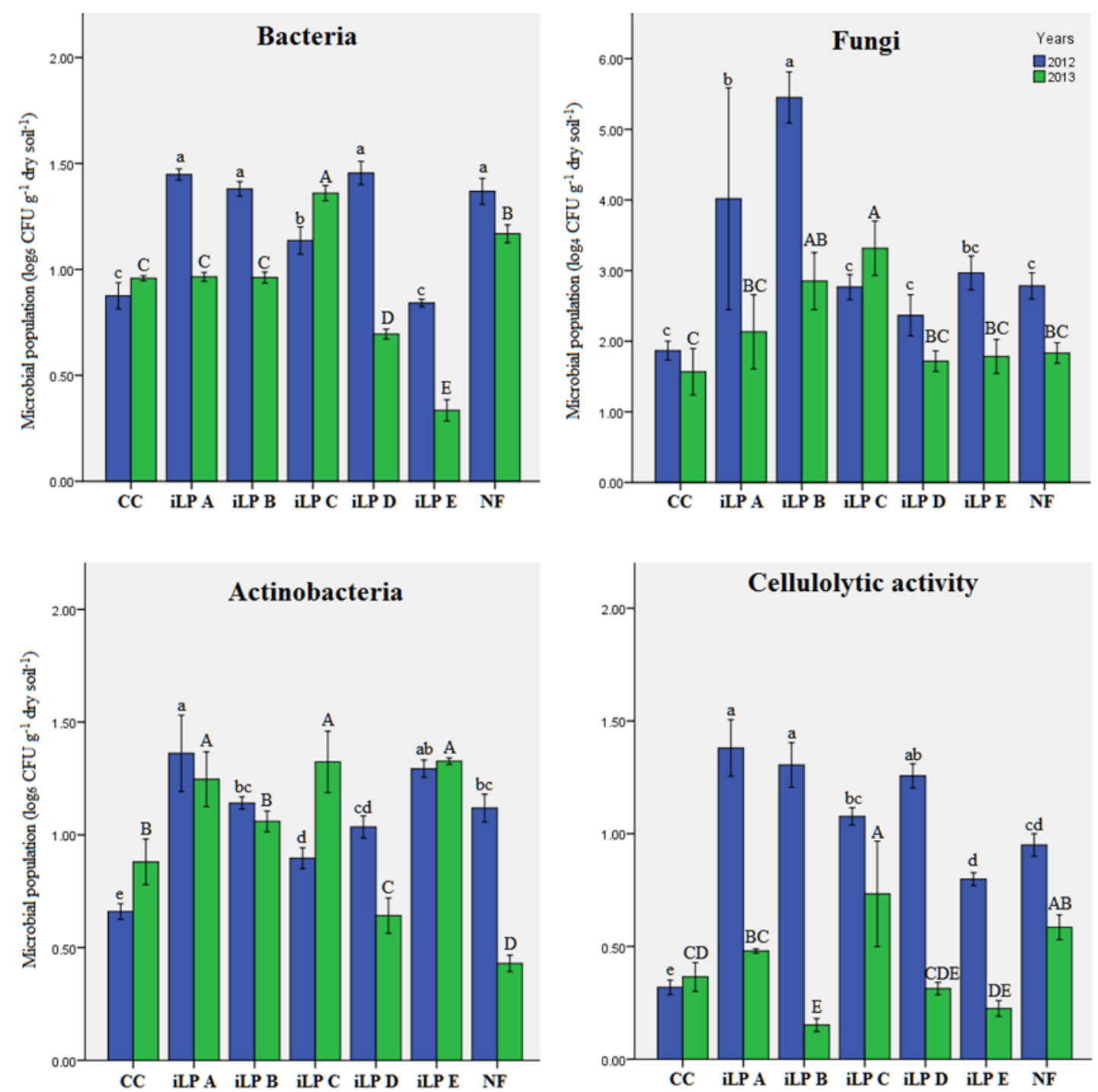

Land use systems Error bars: + $+2 \mathrm{SE}$

Figure 4. Bacterial, actinobacteria and cellulolytic activity of microorganisms population in $\log _{6} \mathrm{CFU} \mathrm{g}^{-1} \mathrm{dry}$ soil $^{-1}$. Fungi are in $\log _{4}$ CFU g ${ }^{-1}$ dry soil ${ }^{-1}$. Sampled soil was managed under seven systems, conventional crop (soybean/maize in succession) (CC), five integrated Crop-Livestock systems (iCL A, B, C, D and E) and native forest (NF), was sampled in the 0.00-0.20 m layer in 2012 and 2013, in the municipality of Santa Carmem, MT, Brazil. Lowercase letters indicate significant differences between systems in 2012 and capital letters compare between systems in 2013 (Tukey test; $\mathrm{p}<0.05)$.

\section{CONCLUSIONS}

The integrated Crop-Livestock systems showed improved soil microbiological qualities after seven years and were more efficient than the conventional system (soybean/maize succession).

The rotation of legumes and grasses preceded by Urochloa brizantha cultivated for two years in iCL $\mathrm{A}$ and $\mathrm{C}$ provided greater synergism of microbiological attributes. These iCL showed increased carbon stocks in microbial biomass, increased soil enzymatic activity and increases in bacterial populations, actinobacteria, fungi and microorganisms with cellulolytic activity. This improvement in soil microbiological attributes highlights the ability of these iCL modules to improve environmental performance, which, in addition to known yield gains, can ensure greater sustainability for agricultural systems.

\section{ACKNOWLEDGEMENTS}

This work was supported with scholarship by CAPES and financial aid from the Fundação AGRISUS (Process- PA 1045/12). The authors are grateful for the assistance of Embrapa Arroz e Feijão and the Programa de Pós-Graduação em Agricultura Tropical - UFMT. 


\section{REFERENCES}

ALEF, K.; NANNIPIERI, P. Methods in applied soil microbiology and biochemistry. ed. London: Academic Press, 1995. 576 p.

ANDERSON, T. H.; DOMSCH, K. H. Application of ecophysiological quotients $\left(q \mathrm{CO}_{2}\right.$ and $\left.\mathrm{qD}\right)$ on microbial biomasses from soils of different cropping histories. Soil Biology and Biochemistry, 22: 251255, 1990.

ASSIS, P. C. R. et al. Biological Soil Properties in Integrated Crop Livestock-Forest Systems. Revista Brasileira de Ciência do Solo, 41: e0160209, 2017.

BALOTA E. L. et al. Long-term land use influences soil microbial biomass $\mathrm{P}$ and $\mathrm{S}$, phosphatase and arylsulfatase activities, and $\mathrm{S}$ mineralization in a Brazilian Oxisol. Land Degradation \& Development, 25: 397-406, 2014.

BLAGODATSKAYA, E.; KUZYAKOV, Y. Active microorganisms in soil: Critical review of estimation criteria and approaches. Soil Biology and Biochemistry, 67: 192-211, 2013.

CHÁVEZ, L. F. et al. Diversidade metabólica e atividade microbiana no solo em sistema de integração Lavoura Pecuária sob intensidades de pastejo. Pesquisa Agropecuária Brasileira, 46: 1254-1261, 2011.

CHEN, X. P. et al. Integrated soil-crop system management for food security. Proceedings of the National Academy of Sciences, 108: 6399-640, 2011.

COUTO, G. M. et al. Response of soil microbial biomass and activity in early restored lands in the northeastern Brazilian Atlantic Forest. Restoration Ecology, 24: 1-8, 2016.

FOLEY, J. A. et al. Solutions for a cultivated planet. Nature, 478: 337-342, 2011

GOMIDE, P. H. O.; SILVA, M. L. N.; SOARES, C. R. F. S. Atributos físicos, químicos e biológicos do solo em ambientes de voçorocas no município de Lavras-MG. Revista Brasileira de Ciência do Solo, 35: 567-577, 2011.

HABIG, J.; SWANEPOEL, C. Effects of conservation agriculture and fertilization on soil microbial diversity and activity. Environments, 2: 358-384, 2015.

JENKINSON, D. S.; POWLSON, D. S. The effects of biocidal treatment on metabolism in soil - V. Method for measuring soil biomass. Soil Biology and Biochemistry, 8: 209-213, 1976.

KANDELER, E.; GERBER, H. Short-term assay of soil urease activity using colorimetric determination of ammonium. Biology and Fertility of Soils, 6: 68$72,1988$.

KLUTHCOUSKI, J.; AIDAIR, H.; COBUCCI, T. Opções e vantagens da Integração Lavoura-Pecuária e a produção de forragens na entressafra. Informe Agropecuário, 28: 16-29, 2007.

LEMAIRE, G. et al. Integrated crop-livestock systems: Strategies to achieve synergy between agricultural production and environmental quality. Agriculture, Ecosystems and Environment, 190: 4 $-8,2014$

MARCUZZO, F. F. N.; OLIVEIRA, N. de L.; CARDOSO, M. R. D. Tendência do número de dias de chuva no estado do Mato Grosso. Ciência e Natura, 34: 59-82, 2012.

MARTHA JUNIOR, G. B.; ALVES, E.; CONTINI, E. Dimensão econômica de sistemas de integração lavoura-pecuária. Pesquisa Agropecuária Brasileira, 46: 1117-1126, 2011.

MUNIZ, L. C. et al. Atributos biológicos do solo em pastagens de diferentes idades em sistema integrado lavoura-pecuária. Pesquisa Agropecuária Brasileira, 46: 1262-8, 2011.

PARIZ, C. M. et al. Tempo de decomposição de massa seca de espécies forrageiras em função de épocas de semeadura no cerrado. In: FERTBIO, 2008, Londrina, Anais... FERTBIO, Londrina, 2008.

PASTOR, A. V. et al. The global nexus of foodtrade-water sustaining environmental flows by 2050 . Nature Sustainability, 2: 499-507, 2019.

PRAMER, D.; SCHMIDT, E. L. Experimental Soil Microbiology. Burgess Publishing. Minnecipolis, Minnesota. 1964. 107 p.

PREVIATI, R. et al. Isolamento e quantificação das populações de bactérias em geral e de Actinomicetos presentes no solo. Arquivo Brasileiro de Medicina Veterinária e Zootecnia, 15: 155-160, 2012.

SALTON, J. C. et al. Integrated crop-livestock system in tropical Brazil: Toward a sustainable production system. Agriculture, Ecosystems and Environment,190: 70-79, 2014.

SANTOS, M. N. Método de controle de plantas daninhas na cultura do cafeeiro e seus efeitos na agregação e em frações da matéria orgânica do solo. 2005. 74f. Tese (Doutorado em Solos e 
Nutrição de Plantas) Universidade Federal de Lavras, Lavras, 2005.

SILVA, A. S. D. et al. Microbial characteristics of soils under an integrated crop-livestock system. Revista Brasileira de Ciência do Solo, 39: 40-48, 2015.

SOUZA, D. M. G.; LOBATO, E. Cerrado: correção do solo e adubação. 2. ed. Brasília, DF: Embrapa Cerrados, 2004. 416 p.

SPSS. IBM SPSS Statistics 19 Brief Guide. SPSS, 2010. $171 \mathrm{p}$.

TABATABAI, M. A. Soil enzymes. In: WEAVER, R.W.; SCOTT, A.; BOTTOMELEY, P. J. (Eds.). Methods of soil analysis part 2 - Microbiological and biochemical properties. Madison, WI: Soil Science Society of America, 1994. SSSA Book Series 5, p. 778-835.

TÓTOLA, M. R.; CHAER, G. M. Microrganismos e processos microbiológicos como indicadores da qualidade do solo. In: ALVAREZ ,V. V. H.; SCHAEFER, C. E. G. R.; BARROS, N. F. de; MELlO, J. W. V. de; COSTA, L. M. (Eds.). Tópicos em ciência do solo. Viçosa, MG: Sociedade Brasileira de Ciência do Solo, 2002. v. 2, p. 195-276.

VENDER, A. Propriedades físicas de um Latossolo Vermelho-Amarelo submetido a sete anos de integração Lavoura-Pecuária no norte de Mato Grosso. 2012. 44 f. Trabalho de Conclusão de Curso - Universidade Federal de Mato Grosso, Sinop, 2012.

VILELA, W. T. C. et al. Pastagens degradadas e técnicas de recuperação: Revisão. PUBVET, 11: 1036-1045, 2017.

WOOD, P. J. Specify in the interactions of direct dyes of polysaccharydes. Carbohydrate Research, 85: 271-287, 1980.

WOLLUM, A. G. Cultural methods for soil microorganisms. In: PAGE, A. L.; MILLER, R. H.; KEENEY, D. R. (Eds.). Methods of soil analysis part 2. 2. ed. Madison, WI: Soil Science Society of America. 1982, p. 781-802. 